\title{
KRONiK
}

\author{
Bu sayının kronik bölümünde, yakın dönemde \\ Türkiye gündemini meşgul eden bilimsel özgürlük ve akademik özerklik \\ konusunu işledik. Bu konuya ilişkin SBF'nin duayen hocaları \\ Prof. Dr. Korkut BORATAV, Prof. Dr. Baskin ORAN ve Prof. Dr. Taner TIMUR'un \\ düşüncelerini almak istedik. Yayın Kurulu olarak söyleşi formunda \\ sorular hazırladik ve hocalarımıza ilettik. \\ Hocalarımızdan gelen cevaplart ilgilerinize sunuyoruz.
}

\section{SBF Hocaları ile Söyleşi: Türkiye'de Bilimsel Özgürlük ve Üniversite}

Öncelikle genel bir değerlendirme sorusu ile başlamak istiyoruz. Akademik özgürlük ile üniversite özerkliği açısından Türkiye'deki son dönem gelişmeleri nasıl değerlendirirsiniz?

Korkut BORATAV (K.B.): İktidarların üniversitelerdeki eleştirel düşünce ortamı ve akademik özgürlükler ile barışık olmaması Türkiye için yeni bir durum değildir. Üniversitelerde görüş ayrılıkları doğaldır. Bunlardan bazıları siyasetle ilgilidir; iktidarları değerlendirir; eleştirebilir; elbette farklılıklar, bazen uzlaşmaz özellikler taşır. $\mathrm{Bu}$, akademik dünyanın doğal çoksesli niteliğinin gereğidir. Normal koşullarda çeşitli akım ve eğilimlere mensup bilim insanları da, bu çeşitliliği, üniversite hayatının normal, sürdürülmesi, savunulması gereken bir özelliği olarak görmekte birleşirler.

$\mathrm{Bu}$ akademik oydaşma kaybolmakta ise üniversiteler için "normal" ortamdan söz edemeyiz. Üniversite çevrelerinde farklı siyasi görüşler içeren bildiriler yayımlandı. Cumhurbaşkanı ile AKP çevreleri bunlardan birini imzalayanlara ağır suçlamalar yöneltti; tasfiyelerini talep etti. Bilim insanlarının sınırsız ifade özgürlükleri, güç odaklarının saldırısına uğrayınca üniversite yönetimlerinin, kadrolarının, mensuplarının tam bir dayanışma içinde olması beklenir. Kapsamlı bir dayanışma bir yana, bir grup meslektaş, iktidar çevrelerinden gelen kampanyaya katıldı; bazı üniversitelerde de tasfiye süreçleri başlatıldı. 
Normal koşullarda beklenen kapsamlı bir dayanışmanın gerçekleşmemiş olması, üç etkene dayanıyor: (1) Üniversite yönetimleri büyük ölçüde siyasi iktidarın denetimi altına girmiştir. (2) Öğretim elemanlarının meslekî güvenceleri, akademik unvanları, terfi süreçleri, bilimsel ölçütlerden çok üniversite yönetimleri tarafından belirlenebilmektedir. (3) Meslektaşlarımızın bir bölümü de "aykırı" görünmekten uzak durmay1, hatta iktidara yaranmayı akademik gelecekleri açısından yeğlemeye başlamışlardır.

Bunlar, Türkiye üniversitelerinin karanlık bir ortam içine sürüklendiğini göstermektedir.

Baskın ORAN (B.O.): Madem bu genel bir soru, genel bir cevap vereyim: 3 tane askerî darbeyi dolu dolu yaşadım, üniversitenin bu kadar bask1 altına alındığını hiç görmedim. 12 Eylül bunların arasında en azgın olanıydı, 1402'yle yaklaşık 70 akademisyeni üniversiteden atmıştı ancak. Şimdi "Bu suça ortak olmayacağız" bildirisi yüzünden "sivil" Erdoğan Rejimi yaklaşık 2.000 akademisyeni işinden etmek için harekete geçti. Sonucu göreceğiz. Kötüye gidiyor Türkiye.

Gidiyor ama aşılanıyor. Bugüne kadar hep askerî darbelerden çıkan kötülükleri gördük ve onlarla mücadele etmeyi öğrendik. Şimdi çoğulculukla/demokrasiyle değil çoğunlukçulukla (majoritarianizm) sandıktan çıkarılan kötülükle mücadele etmeyi öğreniyoruz, aşılanıyoruz.

Taner TIMUR (T.T.): Türkiye'de üniversiteler hiçbir zaman siyasal iktidarlara karşı özerkliklerini koruyamadılar. Ne var ki, askeri darbe yönetimleri bir yana konulursa, AKP yıllarında bu baskılar çok yoğunlaştı ve daha sistematik bir hal aldı. Sonunda da iş cumhurbaşkanının binlerce üniversite mensubuna açıkça hakaret etmesine ve YÖK'ü, rektörleri, savcıları göreve çağırmasına (!) kadar vardı. Üstelik bu Cumhurbaşkanı başkalarına karşı açtığı hakaret davalarından çok para kazandığını söyleyen bir cumhurbaşkanı...

Türkiye'nin siyasal sorunlarının en şiddetli yaşandığı düzlemlerden biri her zaman özgürlük(ler) olmuştur. Basın özgürlüğü, temel insan hakları kapsamında tanımlanan düşünce ve ifade özgürlüğü, bilimsel özgürlük... Bilimsel özgürlüğün algılanışı ve siyasal iktidarın üniversiteyle kurduğu ilişki bağlamında Türkiye'deki tarihsel sürece ilişkin değerlendirmenizi alabilir miyiz?

K.B.: Sorunuzu babam Pertev Naili Boratav ile benim üniversite hayatlarımızdan örnekler vererek yanıtlamaya çalışayım. 
Her ikimiz de meslek hayatımızın bazı dönemlerinde iktidarlarla, dönemin güç odaklarıyla uyuşamadığımız için sorunlarla karşılaştık. Bu tür güçlüklerin nedenleri, patlak vermesi, sonuçları ve aşılması, bugünün gelişmelerine de 1ş1k tutacak bazı özellikler içeriyor.

Babam 1932'de Darülfünun Edebiyat Fakültesi'nde asistandı. Türk Tarih Kongresi'nde Maarif Vekili'nin bir hocasına dönük sert saldırısını dört arkadaşı ile birlikte telgrafla protesto ettiği için üniversitedeki görevinden uzaklaştırıldı. Konya Lisesi'ne edebiyat öğretmeni olarak tayin edildi. Birkaç yıl sonra da Almanya'ya devlet burslusu olarak lisans-üstü çalışmalar için gönderildi. Orada da Hitler rejimini eleştiren konuşmaları, Nazi hayranı olan Berlin'deki Talebe Müfettişi Reşat Şemsettin'e ihbar edildi, bursu kesildi; Türkiye'ye döndü. Önce Siyasal Bilgiler Okulu'na kütüphane memuru olarak atandı. Bir yıl sonra da Maarif Vekâleti Yüksek Öğretim Umum Müdürü Cevat Dursunoğlu'nun aracılığıyla Dil ve Tarih-Coğrafya Fakültesi'ne (DTCF'ye) öğretim üyesi olarak tayin edildi.

Savaş yıllarında anti-faşist bilim insanlarının, yazarların toplandığ dergilerden birisi olan Yurt ve Dünya, DTCF öğretim üyeleri Pertev Boratav, Niyazi Berkes ve Behice Boran tarafindan yayımlanıyordu. Dergi, Türkiye'deki Nazi taraftarı çevrelerin tepkisini çekmekteydi. Bu çevrelerin başlattığ 1 "solcu öğretim üyelerinin tasfiyesi” kampanyası beklenmedik bir gelişme nedeniyle kolay olmadı. 1946 tarihli 4936 sayılı Üniversiteler Kanunu, üniversitelere yönetsel özerklik getiriyordu. Milli Eğitim Bakanlığı'nın DTCF'deki üç öğretim üyesinin görevden alınma talebini, Üniversitelerarası Kurul reddetti. Sonunda tasfiye gerçekleşti; ama istisnaî bir yöntemle, 1948 Bütçe Kanunu'nda bu üç öğretim üyesinin kadrolarına tahsis edilen ödeneğin TBMM tarafindan kaldırılması ile... Böylece babam, kadro açıldığı zaman yeniden atanmak üzere (yarım maaşla ve emeklilik hakkı kısmen korunarak) "açık memur" statüsüne geçti. Emekli oluncaya kadar bu kadro açılmadı ve babam mesleğini Fransa'da sürdürmek zorunda kald1.

1946 tarihli Üniversiteler Kanunu, 1980'li y1llara kadar üniversitelerde ayıklama, tasfiye girişimlerini güçleştirdi; zaman zaman engelledi. 1954'te DP iktidarı tarafindan kanunun değiştirilen bir maddesi ile bu güvence zayıflatıldı. Milli Eğitim Bakanı'na öğretim üyelerini “bakanlık emrine alma” (yani özlük haklarını koruyarak üniversitedeki görevlerinden uzaklaştırma) imkânı tanındı. 1956-1957 ders yılını açan konuşmasında öğrencilerine "nabza göre şerbet vermeyin" çağrısını yapan SBF Dekanı Turhan Feyzioğlu'nun görevine bu yeni düzenlemeye dayanılarak son verildi.

$\mathrm{Bu}$ noktada kendi deneyimlerime geçebilirim. Ben SBF'de akademik mesleğe Üniversiteler Kanunu'nun kurallarına göre başladım. 1961 Anayasası'nın da içerdiği üniversite özerkliği, 4936 sayılı kanuna 1954'te 
getirilen öğretim elemanlarını "bakanlık emrine alma" yetkisini geçersiz kılıyordu. Bu iki boyutlu çerçeve, asistanlıktan başlayarak tüm akademik aşamalara, unvanlara, öngörülen bilimsel ölçütlerin öngörülen sürelerde gerçekleşmesi koşuluyla mesleki güvence sağlamaktaydı. Doktora sonrası akademik unvanlar (doçentlik, profesörlük) üniversite organları (Üniversiteleraras1 Kurul) tarafindan veriliyor; kadrolara atanmalar ise Milli Eğitim Bakanlığı'nın onayı ile gerçekleşiyordu. Bakanlık atamayı gerçekleştirmediğinde görevlerimize doktoralı asistanlar olarak devam edebiliyorduk. Ayrıca, 1961 Anayasası'nın yargı bağımsızlığını geliştiren hükümleri, öğretim elemanlarını siyasi iktidarın keyfî uygulamalarına karşı da koruyordu. Bakanlığın engellemeleri, idari yargı tarafindan iptal edilebiliyor ve atanmalarımız, terfilerimiz mümkün oluyordu. Ben, doçent kadrosuna böyle bir davayı kazanarak atandım.

1946 Kanunu'nun sağladığı mesleki güvence o kadar önemliydi ki, 12 Mart döneminde Sıkıyönetim Komutanlıkları tarafından gözaltına alınan, tutuklanan, yargılanan "muhalif, aykırı" öğretim üyeleri, örneğin SBF'den Mümtaz Soysal, Muammer Aksoy, Bahri Savc1, Cahit Talas görevlerinden alınamadı. Tahliyelerinden sonra görevlerine döndüler; özlük hakları korundu.

Buna karşılık 12 Eylül Rejimi, aykırı akım ve düşüncelerin üniversitelerden kesin tasfiyesini 2547 say1l ve 1981 tarihli YÖK Kanunu ve tamamen değiştirilen 1402 sayılı Sikıyönetim Kanunu aracıllğıyla gerçekleştirmeye kararlıydı. 1946 tarihli kanunda mesleki güvencesi olan doktoralı asistanlar, YÖK düzenlemesi ile sözleșmeli statüye dönüștürüldüler. İlk tasfiye furyasında, bu konumdaki genç meslektaşlarımızdan "sakıncalı" görülenler Rektörlük kararları ile üniversitelerden uzaklaştırıldı. İkinci furyada, Sıkıyönetim Komutanlıkları'nca doçentler ve profesörler için hazırlanan tasfiye listeleri Rektörlüklere iletildi. A.Ü. Rektörü Tarık Somer de, bizlere, "Slkıyönetim Komutanlı̆̆ı'nın talebi üzerine 1402 sayılı kanuna göre bir daha kamu yönetiminde görev alamamak üzere A.Ü. SBF'deki görevimize son verildiği " kararını, pelür kâğıdı ile çoğaltılmış yazılarla tebliğ etti. Şubat 1983 'te bu tebligatı aldığımda 23 buçuk yıllık kamu görevlisi olduğum için emeklilik hakkımı da elde edememiştim.

Sıkıönetimler son bulduktan sonra açılan idari davaların ilk aşamasında mahkemeler "bir daha kamu yönetiminde görev alamama" yasağının ömür boyu süreceği yorumunu yaptı. İlk kez İstanbul'daki bir idare mahkemesi, yasağın sadece sıkıyönetim süresince geçerli olacağı gerekçesiyle davacıyı haklı buldu. Danıştay bu kararı bozdu. Giderek, idare mahkemelerinin iptal kararları birikti. Sonunda Danıştay Başkanı Nuri Alan'ın çabalarıyla oluşturulan bir içtihadı birleştirme kararı, sözü geçen yasağın sadece sıkıyönetim süresince geçerli olacağını kesinleştirdi. Bizler de beş yıl sonra görevlerimize (birikmiş haklarımızı da kazanarak) döndük. 
$\mathrm{Bu}$ anlattıklarım, baba oğul Boratav'ların akademik hayatlarıyla sınırlı değildir. Benzer deneyimlere de bakarak bir genelleme yapabiliyoruz: Siyasi iktidarlar ve devlet, üniversitelerde aykırı sesleri zaman zaman susturmak istemiştir. Ancak, bu çabalar bir türlü kesin sonuç vermemiştir. Üniversiteleri "dikensiz gül bahçelerine dönüştürme" özlemi, bir türlü gerçekleşememiştir. Her döneme özgü karşıt etkenler söz konusu olmuştur.

Pertev Boratav'ın meslek hayatının ilk dönemi, genç cumhuriyetin gelişimini belirleyen iki karşıt kanadın etkisi altında seyretti. İlk kanat, başlangıçta milliyetçilik yaftası altında tutucudur; bilim ve düşün dünyasında "milli değerlerin korunmasına, yabancı ideolojilerin önlenmesine", kısacası, aykırılıkları hizaya getirmeye öncelik verir. $\mathrm{Bu}$ nedenle Boratav'1 Darülfünun'dan uzaklaştırır; Almanya'daki bursuna son verir; daha sonra da DTCF'deki solcu öğretim üyelerinin üniversiteden uzaklaştırılma kampanyasını başlatır; sürdürür. Üniversitenin bu girişimi engellemesini de, Meclis’ten çıkarılan ve hocaların kadrolarını lâğveden bütçe yasası ile etkisiz kılar.

Cumhuriyetin gelişimini belirleyen ikinci kanat ise, aydınlanmacı ve bu anlamda devrimcidir. "En hakiki mürşit ilimdir" ilkesine, dolayısıyla pozitivizme bağlıdır. Bu iki öğenin birlikteliği, düşün ve fikir hayatında çoksesliliği besler; bu çevrelerdeki "aykırılıklar"a hoşgörüyle bakar; "yaramaz çocukları" gözetir. Bu nedenle Boratav'1 önce lise öğretmenliğine, sonra da doktora bursuyla Almanya'ya yollar. "Yaramazlık" tekrarlanınca, önce Mülkiye'de kütüphane memurluğuna, sonra da DTCF'de öğretim üyeliğine getirilir. 1945 sonrasında ise, bilim dünyasındaki "yaramazlıklar" karşısındaki en sağlıklı güvenceyi, yukarıda da vurguladığım gibi, üniversitelere özerkliği getiren 1946 tarihli Üniversiteler Kanunu gerçekleştirdi. İlginçtir ki Cumhuriyet tarihine en demokratik üniversite düzenini getiren bu kanunun mimarı, rejimin aydınlanmacı-pozitivist kanadımı temsil eden Milli Eğitim Bakanı Hasan Âlî Yücel'dir. Kanunun kabulünden iki ay sonra kurulan, Recep Peker hükümetinde Milli Eğitim Bakanlı̆̆ı'na getirilen Reşat Şemsettin Sirer ise tutucu, milliyetçi/reaksiyoner kanadı temsil etmektedir ve üniversitelerdeki tasfiye kampanyasının hükümet içindeki öncülüğünü de üstlenecektir.

Benim akademik hayatımın 1980'li yıllara kadar uzanan büyük bölümünde ise, 4936 sayılı kanunun 1961 Anayasası ile de desteklediği güvenceler geçerliydi. Normal koşulların hukuk ve siyaset ortamında, tasfiyeci uygulamalar imkânsızdı. Bu ortamın da katkılarıyla bu yirmi yıllık dönem, bence, "Türkiye üniversitelerinin altın çağı" olarak nitelendirilebilir.

Ancak, Türkiye toplumunun tutucu, gerici damarı varlığını daima sürdürdü. Siyasete egemen olduğu dönemlerde, "tahammül sınırlarını aşan aykırılıkları tasfiye" hedefini tekrar gündeme getirdi. 12 Mart 1971 sonrasında 
yarım kalan çözüm, 1980 darbesi, YÖK Kanunu ve Sıkıönetim kararlarıyla gerçekleştirilmeye çalışıldı.

$\mathrm{Bu}$ "kesin çözüm" girişimini de, önceki yirmi yılın en önemli kazanımlarından biri olan hukuk devleti, insan hakları, düşünsel ve bilimsel özgürlükler anlayışının birikimi frenledi. Sıkıyönetimler kalktıktan sonra, yasal kısıtlamalara rağmen bu ilkeleri benimseyen, uygulatmaya çalışan yargıçlar çıktı. Tasfiye edilenler mesleklerine döndüler. Akademik mesleğin gereklerini, YÖK'ün kısıtları içinde gerçekleştirmeye çalıştılar.

Şimdi, siyasi iktidardan kaynaklanan yeni bir "temizleme" gündemi içindeyiz. Hukukun temel ilkeleri çiğnenerek, yasal çerçeve dahi zorlanarak bazı meslektaşlarımızın görevlerinden uzaklaştırıldığını duyuyoruz. Yaygınlaşması olasıdır. Yukarıda kısaca gözden geçirdiğim geçmiş deneyimler, bu girişimlerin son tahlilde başarılı olamayacağını gösteriyor. Hukukun evrensel ilkelerini özümsemiş, çeyrek yüzyıl öncesinin Danıştay Başkanı Nuri Alan gibi yargıçlar tekrar son sözü söyleyecektir.

Ancak, o noktaya gelmeden önce, şimdiki mevzileri mümkün mertebe koruyabilmek için, siyaset ve hukuk alanlarında bugünden çetin mücadeleler gerekecektir.

B.O.: Özgürlük, çok çok uzun zamandan beri, 1215 Magna Carta'y1 falan hiç saymıyorum, 17. Yüzyıl ortalarından bu yana Batı'da temel kavramdır, temel düzendir.

Üniversite bu açıdan çok özel bir yere sahiptir. Çünkü mesela bir esnaf konfederasyonunun özerkliği ve özgürlüğü olmasa alışveriş durmaz ve dükkanlar iflas etmez ama, üniversite özerk ve özgür olmazsa bilimsel hayat durur ve memleket iflas eder.

Türkiye'de üniversiteler, sadece 1964-68 arasında özerk ve özgür oldu; 68 Kuşağı lafı oradan gelir. Bu açıdan benim kuşağım çok şanslı. Ondan önce değildi, ondan sonra da kaos ve ardından da 71 ve 80 askerî darbeleri geldi. Şimdi de Erdoğan Rejimi yani görünürde "sivil", ama aslında milliyetçi/dinci vesayet başımıza çöktü.

Niye böyle? Çünkü her ülkede Bileşik Kaplar kuralı geçerlidir. Ülke genel olarak berbat olunca, üniversiteler farklı olamaz. İçinde laçkadır, dışarıdan da baskıdadır.

Böyle olması da çok acayip değil. Biraz da zaman meselesidir bu işler. Düşünün: Oxford 1096'dan beri, Cambridge 1209'dan beri eğitim veriyor. Ankara Üniversitesi 1926' da kuruldu...

Yalnız, verdiğim bu kronolojik bilgiler moral bozmasın. Üçüncü Küreselleşme demek olan Globalleşme sonucu artık her şey olağanüstü hızlı 
gelişiyor. Bakın mesela, Birinci Küreselleşme (1490) ile İkinci Küreselleşme (1890) arasında 400 yıl var, ikincisi ile üçüncüsü (1990) arasında sadece 100 yıl. Çok da fazla beklemeyeceğiz yani.

T.T.: Çok partili dönemde, Türkiye, 1960'larda sosyalist düşüncenin yükselişe geçişine kadar McCarthyist bir atmosfer içinde yaşadı. Gerçekten, Amerikalı senatör daha 1950 'de ülkesinde "elimde bir komünist listesi var!" diye ortaya çıkmamış iken, bizde koyu bir McCarthyism yaşanıyordu. Tan matbaası basılmış; Ankara Üniversitesi rektörü tartaklanarak istifaya zorlanmış; TCK'ndaki sola karşı faşist İtalya ceza kanunundan alınmış ünlü 141 ve 142 'nci maddeleri önce CHP, sonra da DP tarafindan ağırlaștırılmıştı. "Rus salatası"nın adının "Amerikan salatası" olarak değiştirildiği günler yaşıyorduk ve o histeri ortamı içinde sosyalist, komünist olmak şöyle dursun, gerçek anlamda demokrat olmak bile zordu. Sol kanadı olmayan bir parti sistemi ile demokrasi kurulamaz. Elbette aynı koşullar üniversitede de hüküm sürüyordu. Mülkiye'de 1954-58 yılları arasındaki öğrenim yıllarında derslerimizde tek bir kez Marx'ın adının geçtiğini anımsıyorum: O da İktisadi Doktrinler Tarihi'nde, "tüm görüşleri yanlış çıkmış, sahte bir peygamber” olarak.. 27 Mayıs darbesinden sonra, başka vesilelerle tartışma konusu yaptığım bir sürü nedenle, özgürlük marji giderek genişledi. Sosyalist dernekler, Türkiye İşçi Partisi, DİSK kuruldu; Mülkiye'de demokrat bir "Fikir Kulübü" olarak kurduğumuz dernek de giderek "Fikir Kulüpleri Federasyonu"na dönüştü. Üstelik "Kürt sorunu" da ilk kez, yine bu yıllarda TíP bünyesinde dile getirilmişti. Tabii bütün bu gelişmeler üniversitede de ifadesini buldu. Ne var ki 12 Mart 1971 darbesi, gerici bir parlamento çoğunluğu ile işbirliği içinde, bütün bu gelişmelere bir "balyoz darbesi" indirdi ve 12 Eylül 1980 darbesi de çok daha planlı ve sistemli bir şekilde bu süreci tamamladı. Adeta 1950'lerin "McCarthyizm"i yeniden canlanmış ve bu kez komünizme karşı en etkili araç olarak din seçilmişti. Tabii bu durum en çok, devamlı bir "mağduriyet edebiyatı" yapan ve vitrindeki "Atatürkçülük"ün de pek az hışmına uğrayan İslamcıların işine yaradı. Erbakan liderliğindeki "Milli Görüş" hareketi, 12 Mart darbesinden daha üç yıl bile geçmeden bir koalisyon hükümetine ortak olmuștu. Bu akım giderek güçlendi ve 2002 'de de tek başına iktidar oldu. Daha sonra AKP'nin nasıl adım adım Müslüman Kardeşler referanslı bir modele sürüklendiğini hepimiz gördük, yaşadık. Alman Aydınlanması'nın ünlü ismi Immanuel Kant daha 1798'te üniversitelerde felsefenin ilahiyatın önüne geçmesini savunan bir kitap yazmış, özgür üniversitenin kavgasını başlatmıştı; on bir yıl sonra da Almanlar "modern üniversite"nin beşiği sayılan Humboldt Üniversitesi'ni kurdular. Oysa bugün, 2016 yılında, bu ülkede üniversitelerde ilahiyatı felsefenin önüne koyma ve tüm liseleri de İmam-Hatip liselerine çevirme kavgası veren bir parti bulunuyor, iktidarda!.. 
Evrensel değerlere ve uluslararası sözleşmelere göre özgürlükler konusunda bir hiyerarşinin ve farklı dağılımın olamayacağının açıklığına karşın, uygulamada düşünce ve ifade özgürlüğü, ekonomi politik ifadeyle bir "bölüşüm" sorunu olarak da değerlendirilebilir. Kimilerinin daha özgür, serbest, zorlamalardan ve baskılardan muaf olduğu bir toplumsal yapı içinde yaşıyoruz. Bu bağlamda üniversitelerin hem toplumsal hem de kurumsal açıdan bilim ve ifade özgürlüğünü korumak ve geliştirmek için yapması gerekenleri nasıl değerlendirirsiniz?

B.O.: Farklı dağılım olmaz olur mu! Her ülke ve kentin gelişmişlik derecesi farkl1.

Özerklik ve özgürlüğü korumaya gelince, her konuda olduğu gibi üniversite konusunda da fiyat ödemek öne çıar. Üniversite kendi içindeki çürüklere, kendi dışındaki baskılara direndiği zaman acı çeker, ama bu acılar onu özerk ve özgür kılar. Yok öyle, beş kuruşa on köfte. Kimse seni özgür kılmaz. Sen direne direne, acı çeke çeke kendini ve üniversiteyi özerk ve özgür k1larsin.

Tabii, bunları söylerken Batı'daki üniversitelerin kurulması ile bizdekilerin kurulmasının Türkiye için tatsız farklar taşıdığını hatırlamak lazım. Mesela Oxford kurulurken küçük bir kasabada kuruldu. Köylülerle işin başında, iki gün süren ve birçok öğrencinin öldürülmesiyle sonuçlanan ve "St. Scholastica Günü” denilen bir çatışma çıktı (1355'te bir pub'da çıkan ünlü Gowny-Towny [cüppeli - kasabalı] kavgası). Çünkü iki taraf birbirinden çok farklıydı. Aynı dili bile konuşmuyorlardı (Latince ve İngilizce). Ama üniversite Kilise'nin fonlarıyla besleniyordu ve kasabalılara (burjuvalara) karşı onun desteğine sahipti. Diğerleri ise en nihayet köylüydü. Sonunda üniversite kazandı ve kasabadan tamamen özgür, hatta (aristokrasiden aldığı beratlarla) ayricalıklı oldu.

Bugün Harvard ve Oxford gibi küçük yerlerde kurulmuş önemli üniversitelerin gayrimenkulleri, bulundukları kasabalardaki malların ezici çoğunluğunu oluşturur. Ayrıca söyleyeyim, her yıl Oxford belediye başkanı Oxford rektörüne gelir, o söylediğim kavga için törenle özür diler.

Türkiye'de nasıl oldu? Üniversiteler, dünyanın en muhafazakar ve karanlık yerleşim yerleri olan kasabalarda kuruldu. Kuruldu ki, ev sahipleri kolay kiracı, bakkallar da müşteri bulsun, babalar da çocuklarını "gözlerinin önünde" okutsun. Devlet de bu rezaleti oy alabilmek için körükledi babam körükledi. Aynı minvalde devam ediyor olay.

Ben bu düzeni taa Kasım 1981'de, YÖK devreye girmeden tam bir y1 önce Cumhuriyet'te yazdı̆̆ım "Temel Yanlışlık” yazısında zemmetmiştim. 
Demiştim ki, üniversite ancak ve ancak kızlı-erkekli talebelerin birlikte açıkça bira içebildikleri yerlerde kurulur. Taşrada üniversite kurulmaz, çünkü kurulursa taşra modernleşmez, üniversite kasabalılaşır. Üniversite büyük şehirlerde kurulur ki yerel baskılardan mümkün mertebe uzak olsun, mümkün mertebe uygar ortamdan yararlansin.

Eh, maalesef dediğim de çıktı çünkü fazlasıyla doğruydu. Tarım ve balıkçılık gibi teknik konular için neyse ne de, alet-edevat gerektiren tıp fakülteleri ve özellikle de özgür ortam gerektiren sosyal bilimler için kesinlikle doğruydu.

Doğruydu da, başta o zamanki "aydın" hatta "solcu" arkadaşlarım olmak üzere herkes çılgınlar gibi saldırdı, sen nasıl üniversitenin halka inmesine karşı çıkarsın, diye. Al işte, buyur işte şimdi üniversitenin halka inmesini. Son duruma bak: Anadolu üniversitelerinde "Bu suça ortak olmayacağız" bildirisini kazara imzalamış gençlerin durumuna. Evleri işaretlendi. İşyerleri "öğrenciler" tarafından basıldı. Rektörlerce işten atılıyorlar. Bazıları imzasını geri çekti. Bazıları kenti terk zorunda kald1...

Şimdi, bir adım daha atayım ve yine en başta "aydın" ve hatta "solcu" kardeşlerimin, ama aklı başında gibiymiş gibi gözüken herkesin saldırdığı bir olayı daha özetleyeyim de, geleceğe not olsun:

Şöyle yazmıştım: "Böyle giderse eğitim berbatlaşacak ve değerli hocalar da paralı vakıf üniversitelerine kaçacak. Her ihtiyacı olana yeterli burs sağlanmak ve geride kalanların maddi gücüne göre hesaplanmak şartıyla üniversite öğretimi paralı olmalıdır".

Millet sadece son 4 kelimeyi okudu, zavallılar. Nasıl ki, "Aptesli değilseniz namaza yaklaşmayın" sözünden sadece son 2 kelime hatırlanmışsa.

2007 Bağımsız Sol Aday kampanyasında da bol bol kullandılar bunu, zavallılar... Nasıl acıyorum bu insanlara, anlatamam, çünkü kendilerini "halktan yana" sandilar hep.

Ben kızımı DTCF'de bedava okuttum. Oysa, belli bir para verebilirdim ve o parayla başka bir öğrenci okurdu.

"Şey”ler, ancak zaman içinde anlaşılır. Hemen anlaşılmaz. Anlaşılmadığı için de o şey'leri söyleyenlere vasat düzeydeki insanlar fena saldırırlar. Evrensel kuraldır. Sağlık olsun.

T.T.: Üniversiteler özerkliklerini -genellikle uyumlu hareket eden- iki tür “iktidar"a karşı korumak zorundalar; yani iki türlü tehditle karşı karşıya bulunuyorlar. Bunlardan birincisi "Devlet"ten, siyasal iktidardan geliyor. Tabii ikide bir "disiplin" kurullarını toplamaya meraklı, dar kafalı ya da çıkarcı üniversite yöneticileri de bunun aracı oluyor. İkinci tehdit ise iktisadi güç odaklarından, "sermaye"den geliyor. Mütevelli heyetleri "verimli" olmayan, 
"art1-değer yaratamayan" üyeleri, akademik değerleri ne olursa olsun hızla kurumdan uzaklaştırıyorlar. Saydığım bu iki tehditten birincisi daha çok devlet üniversitelerinde, ikincisi ise özel üniversitelerde yaşanıyor. Bunlara karşı mücadele ise ancak kamuoyunda etkin bir konum kazanabilmekle mümkün olabilir. Bu demektir ki işin özü siyasidir ve "üniversiteler siyasetin dışında kalmalıdır" sözü aslında bir aldatmaca olarak sırıtıyor. Elbette ki akademik siyaset, gündelik ve demagojik değil, tam tersine bilimsel analizlere dayanan, aydınlatıcı bir rol oynamalıdır. Bu anlamda üniversiteler, son zamanlarda s1k tekrarlanan bir sözle, bir "üst-akıl” işlevi görmelidir. Öğrencilik yıllarımda Mülkiyeli hocaların başını çektiği FORUM dergisi -tabii yukarıda işaret ettiğim sınırlar içinde- buna bir örnek teşkil etmişti. Menderes'in kişisel tahakküme giden uygulamalarına bilimsel analizlerle karşı çıkmış ve çok da etkili olmuştu. Bugün "bir demokrasi kahramanı" gibi sunulan Menderes bu akademisyenleri hemen üniversiteden uzaklaştırmıştı.

Bir önceki soruda işaret ettiğimiz özgürlüğün eşitsiz dağılımı, Türkiye'de anayasa krizinin bir boyutu olarak da görülebilir. Toplumsal kuruluşun ilkelerini tesis eden anayasada, düşünce ve ifade özgürlüğü ile bilimsel özgürlük birlikteliği sizce nasıl kurgulanmalıdır?

B.O.: Anayasada özgürlüklerin net bir biçimde yer alması çok önemlidir, ama her şeyi halletmez. Mesela, 1982 tarihli (bugünkü) darbe anayasası madde 28 'de "Basın hürdür, sansür edilemez" der, ama daha önce yapılmış bir haberi tekrar yapan Can Dündar ve Erdem Gül bile ne haldedir.

Yukarıda söyledim: Özgürlükler/haklar verilmez. Alınır. Üniversite kendi içindeki çürüklere ve dişındaki uğursuzlara direnir, bedel öder, şu anda da o 2000'e yakın (başlangıçta 1128) çoğu genç akademisyen ödüyor, öyle özerkleşir ve özgürleşir. Yoksa, başka türlü olmaz. Ne kaa ekmek, o kaa köfte.

Biraz çekinerek şunu da söyleyeyim de, genç arkadaşlar bu emekli olmuş, yüksekten atıyor demesinler: Ben zamanında (71 ve 82 ) bu bedelleri asistanken epey ödediğim için rahat konuşuyorum. İşkembe-i kübradan atmiyorum.

T.T.: Haklısınız; bugün ülkede akademik özgürlükler eşit olmayan şekilde kullanılıyor. Ne var ki "çok özgür” görünenler de gerçekte ne kadar "özgür", o da ayrı mesele? Onlar da aslında sermaye düzeninin, maddi çıkarlarının, hatta bazen de Ortaçağ hurafelerinin esiri değiller mi? "Anayasa krizi"nden söz ediyorsunuz; aslında bu kriz yeni bir anayasa yapılmasında ortaya çıkan anlaşmazlıklardan doğmuyor; mevcut Anayasa'nın rafa kaldırılmasından doğuyor. Bu ülke on yıl önce de aynı Anayasa ile 
yönetiliyordu; fakat düşünce serbestliği ve akademik özgürlükler çok daha genişti.

1128 akademisyenin barış bildirisiyle başlayan tartışma, aydın tanımı ile devlet-aydın ilişkisi çerçevesinde yürütülmekte. Kökleri Avrupa'da 18. yüzyıla uzanan bilim-aydın-devlet ilişkisi Türkiye'nin koşullarında nasıl yorumlanabilir?

K.B.: $\mathrm{Bu}$ sorunun ilk bölümüne Kant'ın aydınlanma anlayışı ile 1şık tutabiliriz. Bu felsefeci şöyle diyor: "Hiçbir şey eleştirinin dışında kalamaz: Ne kutsallı̆̆ dolayısılyla din ve ne de yüceliği dolayısıla yasalar. Aydınlanma'nın temel noktasını, insanların devlete, özellikle de dine karşı vesayetten çıkmalarında görüyorum; çünkü dinî vesayet, tüm vesayetlerin hem en zararlısı hem de en onur kırıcısıdır."

Kant, böylece, aydınlanmayı, Orta Çă̆ dünyasına karşı bir isyan olarak yorumluyor. "Hiçbir şey eleștirinin dışında kalamaz..." ifadesi, bu isyanın iki hedefini de belirliyor: Din ve yasalar (yani devlet)... Dinsel dogmalardan ve devletten (yasalardan) kaynaklanan vesayete ve baskıya karşı özgürleşmeden bilim ve felsefe yapılamaz.

Peki, Ortaçağ düzenine karşı bu sınırsız başkaldırıyı yeni düzen (kapitalizm) ile yerleșmeye başlayan paranın vesayetine de taşımamız gerekmiyor mu? Bu soruyu, Kant'tan elli y1l sonra aydınlanma düşüncesinin sonraki (sosyalist) temsilcileri yanıtladı. Örneğin Marx, kapitalist dünyada paranın (sermayenin) vesayeti altına giren düşüncenin hegemonyasını eleştirdi. Dahası, eski düzene karşı başkaldırı tamamlandıktan sonra yeni (kapitalist) devletin geliştirdiği baskı biçimlerine karşı mücadeleye de öncelik tanıdı. Devrimci bir programın son aşamasında devletin "kuruyup yok olması", bu öncelikle bağlantılıdır.

T.T.: Üniversitelerin kurumsal yapıları, onların düzenle uyuşmalarını kolaylaştırıcı bir faktör oluyor. 20. yüzyıl başlarında Fransız eğitim tarihini inceleyen Durkheim, "Şurası dikkate değer bir olgudur ki, tüm Ortaçağ kurumlarından bugün de eski haline en çok benzeyen kurumlar, bazı değişiklerle, üniversitelerdir.” diyordu. Gerçekten de Aydınlanma çağında bile özgürlük kavgası büyük ölçüde üniversitelerin dışında verildi. Voltaire, Rousseau, Montesquieu, Diderot.. vb, bunlardan hiçbiri üniversite mensubu değildi. Sorbon ise ilahiyatçıların sultası altında idi. Sorbon'da reform yapmak isteyen rektör Charles Rollin, bu konudaki ünlü eserini “Allah'tan sonra her şeyini borçlu olduğu krala" ithaf etmişti ve üniversitelerin "üç ana görevi”nden birinin de "dini incelemek ve inançları pekiştirmek" olduğunu yazmıştı. Buna 
karş1lık Diderot'ya göre gerçek bir üniversite bu dar çerçeveyi kıran, "bir ulusun bütün çocuklarına fark gözetmeden (Diderot vurguluyor) kapılarını açan", "evrensel bilimi kucaklayan", "yeni bir üniversite" olmalıydı. Düşünür, Aydınlanma evrenselliği esprisi içinde şunu da ekliyordu: "Kamu eğitiminin ilgi alanında değişen bir şey olmaz.. Amaç bütün yüzyıllarda aydın ve erdemli insanlar yetiştirmektir." Bu konularda "Toplumsal Değişme ve Üniversiteler" (İmge, 2000) başlıklı kitabımda ayrıntılı bilgiler vermiştim; fakat maalesef bu çalışmam en az ilgi gören kitaplarımdan biri oldu.

Yakın zamanda bilimsel özgürlüğün bir gereği ve sonucu olarak bilim insanlarının sadece kamuoyuna seslenişi değil, öğretim ve araştırma süreçleri de suç kapsamında görüldü ve yargıya taşındı. Bilimsel alanda evrensel ilkelere göre suç, bilimsel ve etik ilkelerin ihlali ile sınırlıken, gelinen noktada bilimin cezai yaptırımlara tabi tutuluşuna tanıklık ediyoruz. Bu konudaki değerlendirmelerinizi alabilir miyiz?

B.O.: Başka yerlerde de başka rezaletler olmuştur mutlaka. Ama Mülkiye'de Prof. Gökçen Alpkaya “... Ortak Olmayacağız” bildirisinin uluslararası hukuk açısından bilimsel biçimde incelenmesini isteyen bir soru sordu, soruşturma açıldı, şu anda devam ediyor.

Arkasından yine Mülkiye'de Yrd. Doç. Dr. Barış Ünlü sınavda Öcalan'ın 1978 ve 2012 tarihli iki yazısının belli bilimsel kriterler açısından karşılaştırılmasını isteyen bir soru sordu, mahkemeye verildi. Gerçi beraat etti ama mahkemeye verilmesi büyük skandal idi.

Netice-i kelam: Bu kadar büyük rezaletlere askerî darbe zamanlarında rastlanmadı; şimdi Erdoğan Rejimi zamanında rastlanıyor. Üniversite kendi içinden ve dışından körüklenen bu rezaletlere karşı tek yumruk olursa, özerk ve özgür olur. Olmazsa, eski hamam eski tas olur ve üniversite de bunu hak eder! $\mathrm{Bu}$ rezaletler, üniversite için birer büyük firsattır!

T.T.: Bu konuda galiba ayrıntılı bir "değerlendirme"ye fazla gerek yok; zaten sorunuzda yanıtı da vermişsiniz. 17. yüzyılda Galile'yi yargılayan bu zihniyet, günümüzde de Darwin'i yargılıyor. Bu kafada olanlar, şu ya da bu şekilde, bilimi bir güç aracı haline getirmiş toplumların oyuncağı durumuna düşüyorlar. Gazetelere yansıyan bir habere göre, evrenin oluşmasının ilk anlarını anlamamıza yardımcı olacak Higgs Bozonu ile ilgili buluş için, bir TÜBİTAK üyesi, bilimsel bir toplantıda "bunun Allah'a şirk koşmak!" olduğunu söylemiş! Sanırım bu çok şeyi açıklıyor. 
Farklı ülkelerden yüzlerce akademisyenin Türkiye'deki bilimsel özgürlüğün sınırlandırılmasına karşı tepkilerini gördük. Dünya çapındaki bu yoğun ilgiliyi nasıl yorumlamalıyız? Yaşadıklarımız Türkiye'ye özgü olarak değerlendirilebilir mi, yoksa dünyada böyle bir genel eğilimin var olduğu söylenebilir mi?

B.O.: Sözünü ettiğim rezaletleri, araştırma yapmadım ama, Bat1 üniversiteleri de bundan önce mutlaka yaşamıştır. Çünkü bunlar bugünün rezaletidir ama geçen yüzyılların doğal durumudur; Batılılar onun için tepki gösteriyorlar ve tabii ki Türkiye'yi bu yüzden fena halde aşağılıyorlar.

Ve yine tabii ki, sen aşağılanmayı böyle hak edersen, seni aşağılarlar. Bu kadar basittir.

T.T.: Bir yandan iletişim teknolojisindeki gelişmeler, öte yandan da Türkiye'de (AKP sayesinde olmaktan çok, AKP'ye rağmen) gerçekleşen bilimsel ilerleme, uluslararası planda otuz kırk yıl önce hayal edilemeyecek bir dayanışma olgusu yarattı. 1980'lerde 12 Eylül cuntası yüzlerce akademisyeni üniversiteden atarken Batı'dan pek bir ses çıkmamıştı. $\mathrm{Bu}$ yüzden bugünkü durum çok olumlu bir gelişme ve elbette ki Türkiye ile sınırlı değil. $\mathrm{Bu}$ dayanışmanın AKP uygulamalarına karşı oluşması da bugün Türkiye'yi yönetenlerin "bilimsel özgürlükler karnesi”ni gözler önüne seriyor.

Sorun şüphesiz sadece devlet-üniversite ilişkisi değil. Ayrıca toplumun önemli bir kesiminin üniversiteye yönelik indirgemeci bir talebiyle karşı karşıyayız. Bu talebin içinde üniversitenin yalnızca ve yalnızca bir meslek edindirme kurumu olması, sanayi kesimi için "değer"lendirilebilir bilgi üreten bir işlev görmesi ya da bir sosyal statü kazanmanın aracı olması gibi neoliberal beklentiler yer alıyor. Ayrıca yüksek siyasetin üniversitelerden taleplerini de buna eklemek gerekiyor. Üniversiteler, bu taleplere karşılık vermediğinde ise kolaylıkla açık nefret söylemlerine ve tehditlere maruz kalıyor. Bu muhafazakâr neoliberal iklimde bilimsel özerklik talebinin nasıl canlı tutulabileceği ve üniversitenin nasıl korunabileceği hakkında görüşlerinizi almak isteriz.

B.O.: Meslek edindirme ve insanın zihnini açma fonksiyonları. Üniversitelerde bunların ikisi de bulunur; konusuna göre.

Ama önce başka bir şeye temas etmek lazım. Bu "beklentiler" neoliberal filan değil. $\mathrm{Bu}$ terim icat edilmeden çok çok önce de bu işler böyle idi. 
Üniversite bir zamanlar yedeksubay olup sıyırmanın yoluydu, ayrıca statü kazanmanın, biraz eğlenmenin, daha iyi bir eş bulmanın vs. yolu.

$\mathrm{Bu}$ da çok meşru ve normaldir. Normaldir de, herkesin üniversiteye gitmesinin (yani, "örgün eğitim" denilen şeye ulaşmasının) fiyatı toplum için çok yüksektir. Devletin "özerk ve özgür" olmak isteyen üniversiteye ayırdığg fonlar belliyken ve artmayacakken ve üniversite de bedavayken üniversiteye yüz binlerce kişiyi alırsan, her sınıfa yüzlerce kişi yığarsan, işte ancak bugünkü kalitede eğitim yaparsın.

Tamam; insanların yukarıda sözünü ettiğim ve "sınıf atlamak" olarak özetlenebilecek çok meşru talepleri vardır. Ama bunları üniversite eğitimini "yüksek lise" seviyesine indirgemeye yol açacak biçimde karşılamak şart değildir. "Açık öğretim" diye bir şey vardır.

Artık çok geç ama, sonuç olarak şunu söyleyeyim: Türkiye'de üniversiteler ikiye ayrılmalıdır: Gelişmişler ve gelişmekte olanlar. Birinciler özerk olmalıdır. İkinciler ise, belli kriterlere göre gelişmiş sayılana kadar, birincilerin bir tür vesayeti altına konmalıdır.

$\mathrm{Bu}$ durum aslında şu anda biraz var. Çünkü ikincilerdeki asistanlar lisanüstü yapmak için gelişmiş üniversitelere yollanıyorlar (YÖK Md. 35). Ama sistemleştirmek lazım. Taşra üniversiteleri taşranın vesayetinden ancak böyle biraz kurtulur.

T.T.: Kapitalist düzenin üniversitelere yüklediği işlev gerçekten de böyle. Modern üniversitelerin babası sayılan Humboldt Üniversitesi 1810'da, Almanya'da felsefi tartışmalar eşliğinde, hümanist bir formasyon (Bildung) ideali temelinde kurulmuştu. Ne var ki sonunda sınıf toplumunun kanunları galebe çaldı ve düzeni eleştiren radikaller üniversiteden uzaklaştırıldı. Marx bu koşullarda akademik kariyerden vazgeçmek zorunda kaldı; Feuerbach taşra üniversitelerine sürüldü; Dühring'in bile öğretim hakk1 elinden alındı. İngiltere gibi modern özgürlüklerin beşiği sayllan bir ülkede bile Bertrand Russell, Birinci Dünya Savaşı sırasında barış̧̧ı fikirleri yüzünden Cambridge Üniversitesi'nden kovulmuş, üstelik adli takibata da uğrayarak altı aya mahkûm olmuştu. Ne var ki bugün bizde yaşanan süreç liberalizmin de gerisinde bir potansiyel taşıyor. İktidar çevrelerinde giderek yaygınlaşan anti-kapitalist söylem, kapitalizmi aşmaya değil, onu önceleyen cemaat hayatına dönük bir özlemi ifade ediyor. Gazetelerde Diyanet İşleri Başkanı'nın medreseleri savunan, "medreseler legal olmalı" diyen beyanatlarını okuyoruz. Oysa bu ülkede yüz yıl önce bile "skolastik düşünce" ve "özerk darülfünun" temaları hararetli tartışmaların konusu olmuştu. Örneğin Ziya Gökalp de bu konudaki bir şiirinde şu dizelere yer vermişti. 
"Darülfünun emirlerle düzelmez.

Onu yapar ancak serbest bir ilim.

Bir mesleğe haricinden fer gelmez,

Bırakınız ilmi yapsın muallim!.."

Oysa Erdoğan siyasal kariyerine, yine Ziya Gökalp'e (üstelik asılsız olarak) atfettiği "Minareler süngü; kubbeler miğfer; camilerimiz kışla; müminler asker!" dizeleriyle başladı. Aradaki fark ortada ve bu fark bugün vardığımız noktayı da geniş ölçüde açıklıyor.

Bu konjonktürde bilimsel özgürlük ve akademik özerklik olanağı, yaygın olarak neoliberal ideoloji bağlamında değerlendirilmektedir. Bu iki önemli evrensel değer, piyasa ilişkileri bağlamında araçsallaştırılmıştır. Bu araçsallaştırma ilişkisi dışında üniversiter anlayış tahayyül edilemez olmuştur. Baskıcı devlet yönetimlerine karşı bilimsel özgürlük ve akademik özerklik söylemleri geliştirilirken bir yandan da piyasaya doğru bir savrulma, piyasa dolayımıyla bir özgürleşme iddiası söz konusudur. Sizce gerçekten özerk bir üniversite olanağı var mıdır?

B.O.: $\mathrm{Bu}$ sözler, kimseyi üzmek istemem ama, ezber sözler. Atatürk döneminde neoliberal düzen mi vardı? Atatürk 1933'te üniversiteyi baştan aşağı değiştirdi, çünkü kurduğu otoriter düzenin savunucusu, hatta ideologu olmasını istiyordu. Bunu gerçekleştirdi de. $\mathrm{Bu}$ düzenin mimarı da benim kayınpederimdir, yani eşimin dedesi Reşit Galip Bey’dir.

Diğer yandan, bugün hangi üniversiteler en özgür sesi yükseltiyorlar? İstanbul Bilgi, Sabanc1, Koç. Ne demek istediğim anlaşıldı umarım. Diyorum ki, burjuvazi magandalıktan kurtulduğu ve rafineleştiği oranda üniversite de rahatlar. Niye? Çünkü Türkiye'de bir ulus-devlet düzeni var ve bunun da tanımı şudur: "Egemen etno-dinsel kimlik dışındaki kimlikleri yasaklayan ve onları asimilasyon ve/veya etno-dinsel temizlikle ortadan kaldırmaya çalışan devlet türü”.

Evet, böyle bir tehlike var ama üniversitenin piyasa yönetimine girmesi şu anda acil olay değil. Kendimizi aldatmayalım. Şu andaki acil sorun, üniversitenin bir yandan ulus-devlet baskısından, bir yandan da şeriatçıların baskısından kurtulması. Çünkü bu ikisi şu anda evlenmiş vaziyette.

T.T.: Elbette ki yoktur diyemem; fakat bu konuda elverişli koşullar içinde bulunduğumuzu da kimse söyleyemez. Bizden çok farklı nedenlerle Batılı üniversiteler de kriz içinde bulunuyorlar. Çağdaş kapitalizm her gün biraz daha "uzmanlaşan" ve sonunda da birbirinden tamamen kopuk, çok farklı diller 
konuşan bilim dallarına bölünmüş bir üniversite anlayışını besliyor. $\mathrm{Bu}$ ise üniversiteleri sınıfsal çıkarlara daha da sıkı bağlarla bağlıyor. Ağaçlarla ilgili son derece "rafine analizler" yapan bilim adamları ormanı göremiyor. Üniversite, bir yazarın olumlayarak söylediği "mültiversite”ye dönüştü. Hala aşılmamış olan 2008 krizinin arka planında Nobel ödüllü iktisatçıların ekonometrik modellerinin yattığını unutmayalım.

Son olarak, bilimsel ve akademik özgürlüklerin korunması ve geliştirilmesi için üniversite yönetimlerinin ve yetkili kurullarının izlemesi gereken yola ve belirlemesi gereken tavra dair mesajlarınız alabilir miyiz?

K.B.: Üniversite yönetimlerine yukarıda ileri sürdüğüm görüşler dışında bir mesajım olamaz. Bunun yerine, özellikle genç kuşağın SBF'deki bilim emekçilerine birkaç basit tavsiyem olabilir. Yukarıda değindiğim aydınlanma düşüncesinin rehberliği doğrultusunda çalışmaya devam edin. Hiçbir şeyi eleştirinin dışında tutmadan öğretmenliğinizi ve araştırıcılığınızı sürdürün. Dinsel dogmaların, devletin ve paranın baskısından bağımsız kalmaya özen gösterin. Hatta araştırma gündeminizin hedeflerinden birini de, bu üçlü (din, devlet ve para kaynaklı) baskıyı çözümlemek ve teşhir etmek olarak belirleyin. Ortam bozuk, yakın gelecek belirsizdir. Bilim emekçileri olarak zamanınızı iyi kullanın; bu dar zamanlarda ne kadar çok öğrenir, öğretir ve üretirseniz, karanlık günlerin aydınlığa açılmasını o kadar hızlandırabilirsiniz.

T.T.: "Yetkili kurullara" bugünlerde herhalde şunu hatırlatmak gerekiyor: Yetkilerinizi dikkatli ve adil bir şekilde kullanın ve sakın bu yetkileri aşmayın; bu konuda gelecek baskılara da asla boyun eğmeyin; çünkü bir gün gelir, baskılarla aldığınız "karar"ların hesabı sorulunca kendinizi yapayalnız bulabilirsiniz! Genç akademisyenlere da şunu söyleyebilirim. Her şeyden önce genç bilim adamları arasında bilim özgürlüğü konusunda toplumsal, kurumsal ve kavramsal bir bilincin oluşması gerekiyor. Kolektif dayanışma da ancak böyle ortak bir bilinç ile sağlanabilir. Bunun yolu da, karşılaştırmalı bir yaklaşımla üniversite tarihine, modern üniversitelerin kuruluş koşullarına ve bugün bu kurumların ne gibi sorunlarla boğuştuklarına eleştirel bir yaklaşımla eğilmekten geçiyor. Ben bu konulara ciddi bir şekilde çok geç eğildim. Şimdi genç meslektaşlarıma bu konuda çok daha erken yaşlarda okuma ve incelemeler yapmalarını öneriyorum. Çalışma alanları bu değilse ya da buna zamanları yoksa o zaman da mevcut incelemeleri (ve bu arada benim kitabımı!) okusunlar! 